\title{
Psychological Analysis of Adolescent Deviations
}

\section{Polina Alekseeva}

North-Eastern Federal University in Yakutsk, Russia; E-mail: alinava@inbox.ru

Natalia Prokopeva

North-Eastern Federal University in Yakutsk, Russia; E-mail: nupson@mail.ru

Doi:10.5901/mjss.2015.v6n5s4p225

Abstract

Adolescence is extremely important in everybody's life, since self-image and attitude towards self are shaped in this period. It also accounts for most of the deviant behavior patterns often caused by the deprivation of such needs as affection and safety. Failure to fulfil them results in hostility and aggression, personality neurotization, pursuit of need satisfaction by all means possible. The research covers three groups of adolescents: graffiti drawers, law-abiding teenagers and juvenile offenders. The research has shown that deprivation of the privacy, i.e. private space, choice of friends, own interests and values can trigger deviant behavior among adolescents.

Keywords: deviant behavior among adolescents, deprivation of needs, personality neurotization, self-image, psychological space of personality.

\section{Introduction}

Dramatic social changes at the turn of 21-st century in all life spheres give rise to new fats and phenomena. One of them is a growing variety of deviant behavior patterns among youth and adults. The study of adolescent deviations becomes more and more important these days. Thus, there is a need to create a new methodological approach to the investigation of the deviant behavior patterns among adolescents.

Adolescence is both challenging and important in everybody's life. We observe formation of self-image and attitude towards self, change of the structure and quality of relationships with parents and peers. On one hand, teenagers must psychologically separate from their parents and affirm their uniqueness, on the other hand, find peer understanding and support. This contradiction can lead to role diffusion (Erikson, 1996). Along with hormonal changes, it causes mood swings, increased emotional tension and high sensitivity. For this reason, adolescent deviant behavior is normally characterized by impulsiveness and hastiness of actions together with vague understanding of their consequences. Outbursts of unmotivated aggression, as well as cruelty and violence manifestations are particularly common for teenagers. Adolescence accounts for most of the deviant behavior patterns.

According to the Federal State Statistics Service of the Russian Federation, 47,486 crimes were committed by juveniles or with their assistance from January to October 2014 throughout the country. In addition, rise in the violent crime rates is recorded. Earlier more minor robberies, car thefts and fights were reported. Now violent crimes, suicides and intended bodily harm prevail.

The investigation of the deviant behavior mechanism, apart from its theoretical interest, is of practical importance in terms of juvenile offence prevention.

\section{Literature Review}

This section looks at the definition of adolescent deviant behavior, as well as the main causes of adolescent deviations.

\subsection{Definition of deviant behavior}

Deviation (from the Latin word deviatio - deviation) as one of the personality behavior forms appears and exists in society. It is characterized by a certain level of activity, dynamism, arbitrariness, flexibility, emotional touch and other characteristics and associated with the term "standard of behavior'. Deviation has been defined in two ways: (1) in terms 
of the mental health standards deviant behavior implies explicit or implicit mental pathology, e.g. psychopathy (asthenics, schizoids, epileptoids, etc.), character accentuation (deviations within normal limits); (2) deviant behavior is related to the social and psychological personality status during adaptive interaction with the environment.

Humanistic, psychoanalytic, behavior al, cognitive and environmental investigations associate deviant behavior with personality involvement in social communities, interaction with the surrounding, social and psychic regulation of behavior and delinquency, i.e. illegal behavior .

Kleiberg (2001) highlights the relativity of the term "deviant behavior" encompassing different negative social phenomena such as crimes, drug and alcohol abuse, suicides, etc.

In psychology, the term "deviant behavior" is mainly used for unsocial, asocial and self-injurious behavior s as disadaptation manifestations in adolescence (Zmanovskaia, 2012).

In this study aimed at psychological analysis of the adolescent deviation causes, the term "deviant behavior" will be regarded as social disadaptation and violation of legal, moral and social standards (delinquency, alcohol abuse, excessive gambling, graffiti, vagrancy, etc.).

\subsection{Causes of adolescent deviations}

Adolescence has always been considered a time of particular physiological and social vulnerability and extraordinary susceptibility to the environmental influences, both positive and negative. Social contexts shape adolescent attitudes and behavior s.

Deviant behavior can be caused by biological, psychological and social factors. There are three main directions in the adolescent deviation psychology as a cross-disciplinary research area (Zmanovskaia, 2012):

- Exploration of biological determinants of deviant behavior. This direction was established and developed by Lombroso (2011), Sheldon (1954), Eysenck (1999) and others. Speech disorders and physical defects attract people's involuntary attention causing difficulties with interpersonal relationships and adaptation to the environment and generating deviant behavior.

- Study of psychological factors of deviant behavior. The study focuses on psychic reality predetermining a psychic image of adolescents. According to research, deviant behavior is accompanied by excessive anxiety and aggression, constriction, lack of self-confidence, low social status, etc. Belicheva (1994) concludes that alteration of values and attitudes is the main cause of deviant behavior in adolescence.

- Investigation of social factors underlying adolescent deviations. Gilinskiy (2007) analyses the theories suggesting that deviance is as a result of a conflict between strive for success and a real opportunity for it. It can result in formation and demonstration of own values and standards.

Thus, the most common causes of adolescent deviations include biological (poor physical appearance), psychological (individual characteristics) and social (different values and standards).

Kon (2006) states that adolescence is a time of considerable risk particularly focusing on manifestations of violence and aggression among adolescents. Vandalism, blackmail, bullying and other adolescent deviations are common for groups susceptible to emotional contagion where irresponsibility and impunity reign. Petrovskiy (2007) views adherence to any antisocial subculture as a deviation factor. Recent studies examine the impact of the Internet, video games and movies on the deviation manifestations (Belinskaya, 2013; Voiskounsky, 2010, et al.).

\subsection{Deviations as replacement behavior $s$}

In societies that are undergoing or have undergone deep transformation, significant change in personality traits is observed.

Lewin (2000), Frager and Fadiman (2004), and Heckhausen (2001) believed that in societies experiencing drastic changes, the conflict occurs between the need and the need satisfaction method engendering replacement behavior . For instance, vandalism is "destruction for destruction's sake". Vandals behave senselessly, however, act reasonably. According to research, replacement behavior involves manipulations with the replacement item to let off some of accumulated energy and get rid of the feeling of something missing, although such manipulations cannot satisfy the need completely. Deprivation of the need can lead to personality neurotization, if the need is not satisfied further.

Apart from the basic biological needs of food, drink and sleep, a person is born with the other needs such as interaction with the surrounding, cognitive need, etc. Psychologists say that mental development is possible only subject to interaction with the outside world. Mental processes develop and manifest themselves in relationship and communication that are the most important forms of people's life. While interacting, people establish contacts and ties, 
influence each other, engage in joint actions and feel identically. As a result, people develop healthy personalities. Otherwise, lack of interaction can cause long-lasting negative emotional state affecting further personality development.

Thus, deprivation of needs generates replacement behavior and personality neurotization.

Adolescents are amazingly ambivalent, no longer children, but not quite adults either. Psychologists believe that the most important feeling they have to develop in adolescence is the feeling of being adult. According to Erikson (1996), the main task of an adolescent is to collect all information about own personality (what kind of son, daughter, brother, sister, student, sportsman, client, etc. am I) and form a comprehensive self-image. Forming self-image seeks confirmation of own identity by the outside world.

If society accepts and supports all doubts and pursuits of adolescents, they can develop an adequate futureoriented self-awareness.

Horney (2013) asserts that healthy social surrounding, i.e. care, acceptance, respect by other people make adolescents feel that they belong to healthy and safe environment. By contrast, if adolescents get no attention, support and care from others, they feel fear, anxiety and uneasiness. Horney (2013) believes it results in a neurotic personality striving to satisfy his/her neurotic needs.

A sense of belonging and safety is highly relevant for adolescents. Deprivation of these needs causes need replacement and personality neurotization. Teenagers tend to meet their needs by any means possible demonstrating deviant behavior patterns.

\section{Research Methodology}

\subsection{Participants}

Three groups with a total of 120 adolescents aged 13-17 years were invited to participate in the study. The first group consisted of law-abiding teenagers, while the second one was comprised of juvenile offenders having a police record or serving a sentence. The third group contained teenagers who regularly drew graffiti and adhered to the graffiti subculture.

\subsection{Instrument}

A methodology for the investigation of psychological space by Nartova-Bochaver (2005) was used in this study. Psychological space of a personality includes physical, social and other psychological phenomena, i.e. space, personal belongings, social affections, attitudes, etc. The questionnaire contains 80 questions embracing six scales used for measurement of the psychological space: 1. Body sovereignty (BS); 2. Space sovereignty (SS); 3. Sovereignty of personal belongings (SPB); 4. Sovereignty of habits (SH); 5 . Sovereignty of social contacts (SSC), 6 . Sovereignty of values (SV). The respondents had to fill in the questionnaire following the instructions below: "You are expected to assess the statements describing a person's childhood. If the statement is true for you, put a tick in the "Yes" box. If the statement is false for you, put a tick in the "No" box. If you cannot recall all of the details, consider the most likely scenario. This questionnaire does not measure your intelligence. There are no right or wrong answers. Any of the options can be met in real life. Try not to think too long before you make a choice. The questionnaire will take twenty minutes to complete. Thank you."

To build an identification matrix, a "Who Am I?" technique as an arbitrary self-description was employed. It was developed by Kuhn and McPartland in 1954. It has several Russian modifications. We used the one by Rumiantceva (2009). The respondents were supposed to give as many answers as possible to the question "Who Am I?" The respondents had to write down the answers as they appeared in their minds. Then they had to put (+) if the quality was positive, (-) if negative, ( \pm ) if ambivalent, or (?) if they did not know the answer. The scale of identifying characteristics contains 24 indicators combined to form seven general components of identity: 1) "Social Self", 2) "Communicative Self", 3) "Material Self", 4) "Physical Self", 5) "Acting Self", 6) "Promising Self", 7) "Reflexive Self" comprising two indicators, 8) Unclear Identity.

The data were processed and analyzed using SPSS Version 17.0 for Windows and Microsoft Office applications. To reveal the differences between the representative samples, the Mann-Whitney $\mathrm{U}$ test was performed. 


\section{Findings and Discussion}

\subsection{Graffiti and self-image}

Graffiti (from the Italian word Graffito - "scratched") are anonymous non-institutional writing or drawings scribbled or painted in public places. Graffiti art has become extremely popular among youth in recent years. Graffiti includes any graphics applied to wall surfaces: from simple written words to elaborate paintings designed to impress people around.

According to Skorokhodova (1998), adolescents who draw graffiti long to tell everybody about their lives, gain recognition, appreciation, and respect from their surroundings. They also rebel against the existing cultural standards, while having fun drawing wherever they want.

We assumed that teenagers who draw graffiti seek to express themselves through the art. The Reflexive Self dominates in their personality structure as a reflection of their unique identity and strong desire to tell the world about their feelings and thoughts.

Two groups of adolescents were invited to participate in the study. The first group consisted of the graffiti drawers, while the second one contained the teenagers who had never done graffiti or had tried it once.

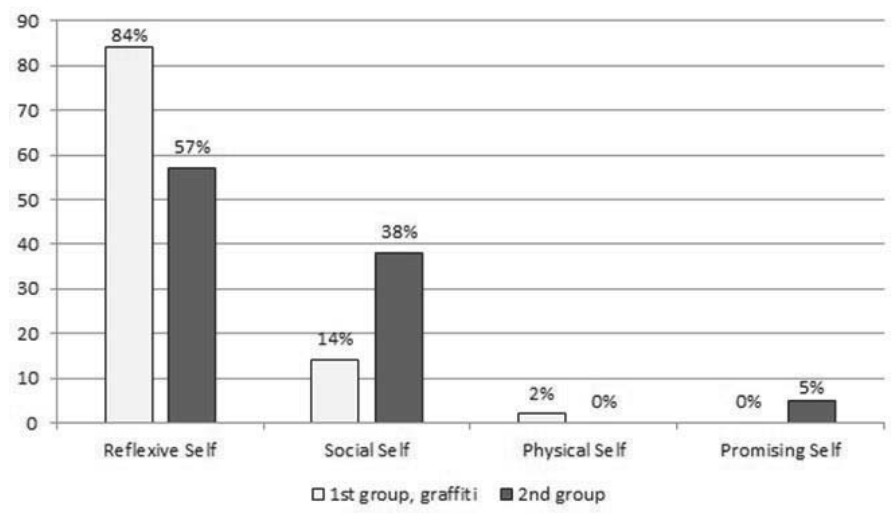

Figure 1. Identification Matrix for the Two Groups

The analysis of the adolescent identification matrix reveals the prevalence of the Reflexive and Social Selves along with the Physical and Promising Selves. The matrix shows no Communicative Self as an awareness of peer group affiliation, as well as no Material and Acting Selves as an attitude towards material possessions and self-fulfillment through work. The above findings represent a specific character of the group under consideration.

The first group is comprised of the adolescents with the dominant Reflexive Self, i.e. those who express themselves through drawing, whereas the second group contains the adolescents with the strong Social Self (educational or professional identity, ethnic, religious, or sex identity). The comparison of the identification matrices shows that the teenagers who do not do graffiti concentrate on the Promising Self, i.e. future-oriented intentions, wishes and dreams, while the teenagers from the other group focus on the Physical Self, as their visual appeal is important for their selffulfillment.

Table 1. Mann-Whitney U Test Results for the Two Groups.

\begin{tabular}{|lcc|}
\hline & Reflexive Self & Social Self \\
\hline Mann-Whitney U statistic & 996.500 & 890.500 \\
\hline Wilcoxon W statistic & 2592.500 & 2165.500 \\
\hline Z & -2.556 & -3.120 \\
\hline Asymptotic significance (two-tailed) & 0.011 (differences revealed) & 0.002 (significant differences revealed) \\
\hline
\end{tabular}

The Mann-Whitney $U$ test used to compare the two groups revealed the differences between the groups $(0.011, p \approx 0.05)$ 
on the Reflexive Self scale. Teenagers doing graffiti demonstrate more confidence in own uniqueness and exclusiveness and strive to stand out among peers.

On the Social Self scale, the Mann-Whitney $U$ test revealed significant differences between the groups $(0.002$, $p \approx 0.01$ ). Teenagers who do not draw graffiti have a more developed Social Self. It confirms that they express their identities through social interaction and affiliation with various social groups, whereas the teenagers who draw graffiti assert their personal identities ("I am cool", "I am great"). Moreover, the identification matrix for the adolescents who do not do graffiti contains the Promising Self as future orientation, potential self-fulfillment in different life spheres (e.g. family, career, hobby, sport, etc.). By contrast, the matrix for the graffiti drawers contains the Physical Self as selfpromotion (I am beautiful and smart, have ideal proportions, like fast driving, etc.) and self-assertion through personal exclusiveness.

Thus, deprivation of the sense of belonging, i.e. no attention, care and support from the surrounding results in the neurotic desire to remind others of own unique individuality.

\subsection{Personal space and safety need}

A new survey of adolescents aged 13-17 years has shown that the most deprived need for them is the one of safety, while adults mostly fail to satisfy the need for personal growth and development.

According to Horney (2013), what adolescents need most is safety, i.e. love, acceptance and protection from the hazardous and hostile world outside. They say that their home is their castle, the place where they may return whatever happens. Parents are supposed to satisfy the need for safety. Friendship between parents and teens is a foundation for a healthy and adequate teen personality. Alternatively, if parents fail to meet this need, a teen may have a neurotic personality. We believe that deprivation of the need for safety predetermines adolescent territorial behavior.

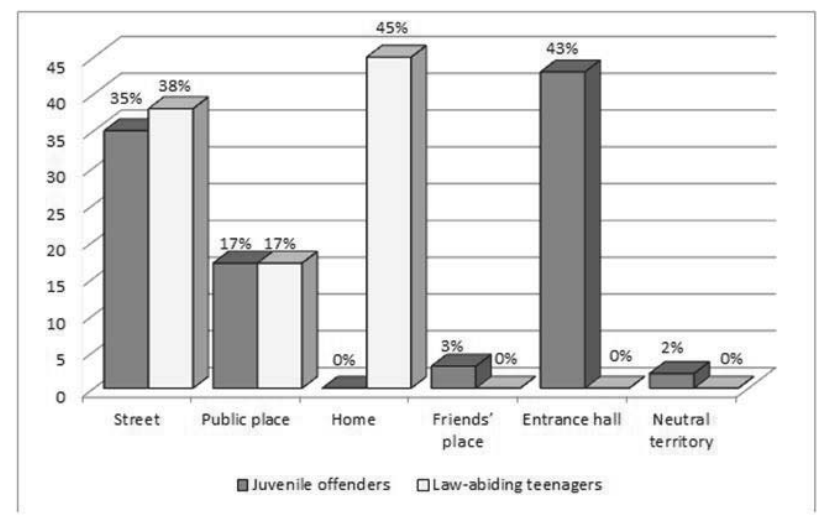

Figure 2. Places Where Teenagers Like to Spend their Time

The research has revealed that the law-abiding teenagers prefer to spend their free time at home (55\%), on the streets $(38 \%)$ or in public places (cafes, cinemas, squares, parks, etc.) (7\%). Meanwhile, the juvenile offenders spend their free time in entrance halls (43\%), on the streets (35\%), in public places (17\%), at friends' places (3\%) or on roofs of high-rise buildings (2\%).

Thus, we observe different territorial behavior patterns in the two groups. Territorial behavior is associated with the environment ensuring certain level of social interaction. Adolescents personalize their relationships with others, demonstrate their things, values and interests to show themselves and their group affiliation. Pliusnin (1990) believes that territorial behavior is intended to facilitate personality identification through the establishment of the physical borders between the self and others, as well as support the social regulation. Territorial behavior varies depending on the place and subject. It also has time characteristics and rules whose violation engenders deprivation. 
Table 2. Difference in Territorial Behavior between the Groups under Consideration

\begin{tabular}{|c|c|c|c|c|}
\hline & & & Juvenile offenders & Law-abiding adolescents \\
\hline \multirow{6}{*}{ Spearman's rho } & \multirow{3}{*}{ Juvenile offenders } & Correlation coefficient & 1.000 & $-.528^{*}$ \\
\hline & & Significance (two-tailed) & . & .043 \\
\hline & & $\mathrm{N}$ & 15 & 15 \\
\hline & \multirow{3}{*}{ Law-abiding adolescents } & Correlation coefficient & $-.528^{*}$ & 1.000 \\
\hline & & Significance (two-tailed) & .043 & . \\
\hline & & $\mathrm{N}$ & 15 & 15 \\
\hline
\end{tabular}

*. Correlation is significant at the 0.05 level (two-tailed).

Spearman's correlation analysis for connected ranks has revealed significant differences between the territorial behavior patterns of the two groups $(r=0.94, p \approx 0.01)$. Therefore, we can conclude that juvenile offenders tend to form cliques with peers and look for ideal outside the family, whereas law-abiding teenagers usually open their home to their friends. Their parents know their friends by name and sight. Sometimes their parents even know their friends' families.

While law-abiding teenagers defend their values and attitudes inside the family, juvenile offenders seek to satisfy this need outside the family. We can assume that juvenile offenders who are not able to defend their views may demonstrate deviant behavior to satisfy the need for autonomy.

In parent-child relationships, adolescents tend to ask their parents for help in solving their problems. Their parents admit the possibility of changes in teens' behavior and emotions and become more sensitive to these changes and flexible in relationships with their growing up children. However, they may find it difficult to get rid of the stereotypes that dictate what one can and cannot do imposed by the society. Moreover, previous behavior al experience does not allow adolescents to accept a new behavior model causing behavior problems.

Teenagers generally pay more attention to their peers rather than parents and try to create their own hierarchy of values. In adolescence, growing criticism weakens the sense of safety. The need for emotional contact is satisfied through affiliation with informal groups, where teenagers gain friendship and adaptation experience, as well as acceptance and support from other group members. Thus, peers satisfy the teenagers' need for recognition and safety.

\subsection{Personality interaction with the environment}

As has already been stated, personality develops continuously as a result of social interaction. In addition, self-concept and attitude towards self and the world in general are formed during social interaction. Libin (2004) believes that interaction with the outside world has such characteristics as intensity (activity of personality), stability and variability (various behavior al strategies), width and narrowness of interaction range (articulation of behavior), involvement and distantness (degree of autonomous functioning). For adolescents, autonomous functioning is the main characteristic of social interaction. For any person, personal space is of paramount importance. It is no accident that both at home and at work we strive to create our own place with our belongings reflecting our personalities, habits and affections.

According to Nartova-Bochaver (2005), each person has his or her own psychological space formed throughout life. It includes own body, belongings, dwelling, tastes, beliefs and values. Own physical space usually appears during manipulations and locomotions. A person moves from one room to another thus establishing the borders between personal and non-personal space (Nartova-Bochaver, 2008). Personal autonomy is a result and factor of non-violent, respectful attitude towards a person along with similar attitude of a person towards the surrounding. Psychological space is a condition and result of a productive activity in different life spheres. According to Nartova-Bochaver (2008), it can correlate with the objective and subjective success indicators.

Modern social and historical processes place even more pressure on personal autonomy, own psychological space, freedom and responsibility. The problem of the space violation is of the utmost importance, since it affects all spheres of human life.

While analyzing adolescent deviations, we suggested that there would be differences in the level and structure of sovereignty (autonomy) of psychological space between the three groups of respondents: law-abiding teenagers, graffiti drawers and juvenile offenders. 120 adolescents aged 13-17 years were invited to participate in the study.

Generally, we observe a medium level of sovereignty of psychological space across all the samples in the above groups. Thus, we may conclude that more than half of the respondents in each group have their own identities. They are adapted to the environment and ready to tackle the age problems. However, there are also significant differences 
emphasizing the peculiarities of each group.

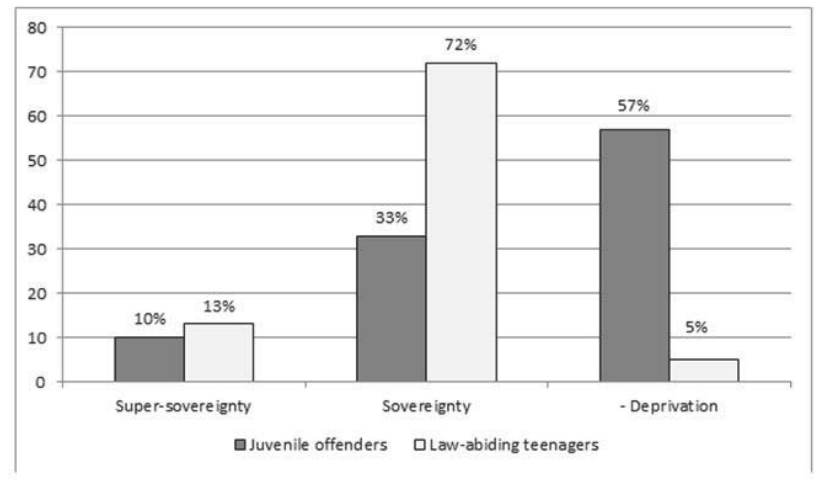

Figure 3. Sovereignty Distribution by the Groups

As we can see in Figure 3, juvenile offenders demonstrate lower sovereignty levels and less frequently reach the supersovereignty area. Deprived sovereignty in more than half of the juvenile offenders participating in the study (57\%) suggests that juvenile offenders find it difficult to satisfy the need for autonomy. They easily become victims of other people's invasion. They cannot choose the right psychological distance to hazards and threats and often feel impotent trying to defend personal boundaries. Unfortunately, such teenagers cannot defend and control everything that appears and exists inside their psychological space. Law-abiding adolescents show an adequate sovereignty of psychological space $(72 \%)$. They can defend and control their psychological space and choose the right psychological distance to people around them. They feel no adult pressure and can resist or avoid destructive external influences. For internal psychological comfort, it is important to have at least a bit of personal space where teens can feel, rest, hide, etc.

Table 3. Differences in Psychological Space Components (Mann-Whitney U Test)

\begin{tabular}{|l|c|}
\hline & Space sovereignty \\
\hline Mann-Whitney U statistic & 320.5 \\
\hline Wilcoxon W statistic & 848.5 \\
\hline Z & -2.59 \\
\hline Asymptotic significance (two-tailed) & 0.01 (differences revealed) \\
\hline
\end{tabular}

The Mann-Whitney $U$ test revealed significant space sovereignty differences between the juvenile offenders and lawabiding teenagers $(0.04, p \approx 0.05)$. The law-abiding teenagers have more deprived space sovereignty. It is explained by the fact that they are more concerned about the loss of space boundaries and invasion of personal space. They are more susceptible to external influences and tend to behave in socially acceptable ways. It is not mere submission but the acceptance of traditional values together with the respect for adults. 


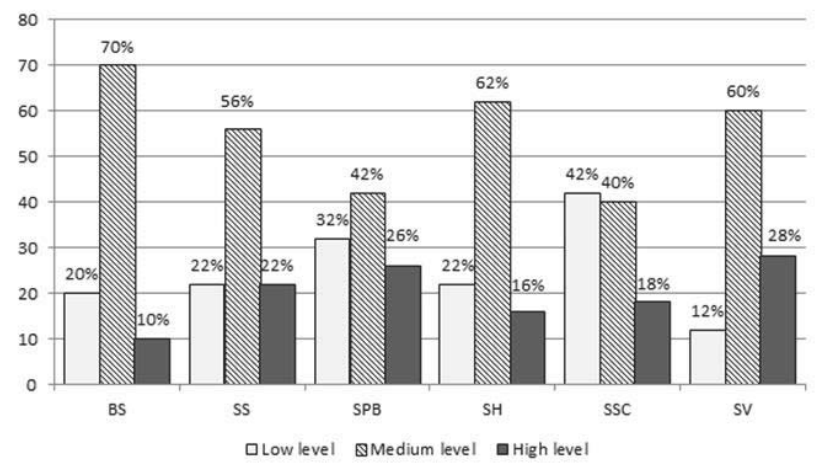

Figure 4. Psychological Space of Graffiti Drawers

The graffiti drawers are deprived of the right to choose friends and other people around them. Their social contacts are strictly controlled by their family. In this context, graffiti can be considered as an act of protest showing teens' desire to choose friends and hobbies independently. They are also deprived of the right to have personal belongings. Graffiti allows them to express their feelings and emotions, as well as communicate values.

Lewin (2004) asserts that life space changes when personality develops. Value system undergoes a drastic change in the course of time. Personal tastes and values as psychological space characteristics reflect personal attitudes and make up the core of the belief system while influencing the interaction with the outside world. They cannot help to survive, i.e. cannot satisfy primary needs. However, they offer potential for future development. According to NartovaBochaver (2008), tastes and values are "reserve components" of the system enabling individualization.

Table 4. Spearman's Correlation for Connected Ranks between the Values of Juvenile Offenders and Law-abiding Teenagers

\begin{tabular}{|c|l|c|c|c|c|}
\hline & & Juvenile offenders & Law-abiding teenagers & $\mathrm{d}$ & $\mathrm{d} 2$ \\
\hline 1 & Friendship & 1 & 3.5 & -2.5 & 6.25 \\
\hline 2 & Freedom & 2.5 & 1 & 1.5 & $\mathbf{2 . 2 5}$ \\
\hline 3 & Family & 4 & $\mathbf{2}$ & $\mathbf{2}$ & $\mathbf{4}$ \\
\hline 4 & Thirst for knowledge & 5 & 6 & -1 & 1 \\
\hline 5 & Trust & 6 & $\mathbf{8}$ & -2 & $\mathbf{4}$ \\
\hline 6 & Comfort & 2.5 & 3.5 & -1.5 & 2.25 \\
\hline 7 & Safety & 8 & 5 & 3 & 9 \\
\hline 8 & Health & 7 & 7 & 0 & 0 \\
\hline & & & & & $\mathbf{2 8 . 7 5}$ \\
\hline
\end{tabular}

$\mathrm{Ta}=0.5 \mathrm{~TB}=0.5$

$r=0,65 p \leq 0.01$. statistically significant.

Table 5. Values Ranking in the Study Samples

\begin{tabular}{|c|l|c|l|}
\hline & Juvenile offenders & & Law-abiding teenagers \\
\hline 1 & Friendship & 1 & Freedom \\
\hline 2 & Freedom & 2 & Family \\
\hline 3 & Family and comfort & 3 & Friendship and comfort \\
\hline 4 & Thirst for knowledge & 4 & Safety and health \\
\hline 5 & Trust & 5 & \\
\hline
\end{tabular}

The analysis of the values of the law-abiding teenagers has shown that they tend to meet the expectations of their parents, teachers and society in general and follow social norms and standards. Law-abiding teenagers appreciate freedom, family, safety and health, while for juvenile offenders friendship and freedom are of primary importance. 
Table 6. Difference in Value Sovereignty (Mann-Whitney U Test)

\begin{tabular}{|l|c|}
\hline & Sovereignty of values \\
\hline Mann-Whitney U statistic & 307 \\
\hline Wilcoxon W statistic & 835 \\
\hline$Z$ & -2.78 \\
\hline Asymptotic significance (two-tailed) & 0.005 (differences revealed) \\
\hline
\end{tabular}

The Mann-Whitney $U$ test revealed significant value sovereignty difference between the juvenile offenders and lawabiding teenagers $(0.03, p<0.05)$. The juvenile offenders demonstrate lower value sovereignty deprivation levels.

Thus, we can conclude that the value structure of law-abiding teenagers is primarily based on the traditional value system unlike the value structure of the juvenile offenders.

The sovereignty of life space and its components - sovereignty of body, personal space and belongings, habits, social contacts, tastes and values - shows the boundaries of psychological space inside which a person feels comfort or discomfort. Discomfort often causes replacement behavior and personality neurotization.

\section{Concluding Remarks}

The analysis of adolescent deviant behavior shows that adolescents tend to form cliques with peers and copy their behaviors. They may also demonstrate excessive aggression and violence, act impulsively without considering the consequences of their actions and deny their guilt. In fact, they just try to understand themselves and their place in the world. Adolescent deviations may be caused by the deprivation of the safety and affection need that is extremely important for adolescents. Failure to fulfill this need results in hostility and aggression, personality neurotization and pursuit of need satisfaction by all means possible.

\section{References}

Belicheva, S.A. (1994). Osnovy preventivnoi psikhologii [Fundamentals of preventive psychology]. - Moscow: Sotsialnoe Zdorove Rossii. [in Russian]

Belinskaya, E.P. (2013). Informational socialization in adolescents: experience of using social networks and psychological well-being. IIPsikhologicheskie Issledovaniya, 6(30). [in Russian]

Erikson, E. (1996). Identichnost: yunost $i$ krizis. [Identity: youth and crisis]. - Moscow: Progress. [in Russian]

Eysenck, H. (1999). Struktura lichnosti [The structure of human personality]. - St. Petersburg: Yuventa. [in Russian]

Frager, R., \& Fadiman, J. (2004). Teorii lichnosti i lichnostnyy rost [Personality and personal growth]. - Moscow: Mir. [in Russian]

Gilinskiy, la.I. (2007). Deviantologiya: sotsiologiya prestupnosti, narkotizma, prostitutsii, samoubiistv i drugikh otkloneniy [Deviantology: sociology of crime, drug addiction, prostitution, suicide and other deviations]. - Moscow: Yuridicheskii Tcentr Press. [in Russian]

Heckhausen, H. (2001). Trevoga i trevozhnost. [Worry and anxiety]. - St. Petersburg: Piter. [in Russian]

Horney, K. (2013). Nevroticheskaya lichnost nashego vremeni. Novye puti v psikhoanalize. [The neurotic personality of our time. New ways in psychoanalysis]. - St. Petersburg: Piter. [in Russian]

Kleiberg, lu.A. (2001). Psikhologiya deviantnogo povedeniya [Psychology of deviant behavior]. - Moscow: Sfera. [in Russian]

Kon, I.S. (2006). Mezhdistciplinarnye issledovaniia. Sotsiologiya. Psikhologiya. Seksologiya. Antropologiya [Cross-disciplinary research. Sociology. Psychology. Sexology. Antropology]. - Rostov-on-Don: Feniks. [in Russian]

Lewin, K. (2000). Teoriya polya v sotsialnyx naukax [Field theory in social sciences]. - St. Petersburg: Rech. [in Russian]

Libin, A.V. (2004). Differentsialnaia psikhologiia [Differential psychology]. - Moscow: Akademia. [in Russian]

Lombroso, C. (2011). Genialnost i pomeshatelstvo [Genius and insanity[. - Moscow: Akademicheskii Proekt. [in Russian]

Nartova-Bochaver, S.K. (2005). Psikhologicheskoe prostranstvo lichnosti [Psychological space of personality]. - Moscow. [in Russian]

Nartova-Bochaver, S.K. (2008). Chelovek suverennyi: opyt psikhologicheskogo issledovaniya subekta $v$ ego bytie [Sovereign person: psychological study of a person in his/her being]. - St. Petersburg: Piter. [in Russian]

Petrovskii, A.V. (2007). Psikhologiia i vremia [Psychology and time]. - St. Petersburg: Piter. [in Russian]

Pliusnin, lu.M. (1990). Problema biosotsialnoi evoliutsii [Problem of biosocial evolution]. - Novosibirsk. [in Russian]

Rumyantseva, T.V., \& Ivanova, N.L. (2009). Sotsialnaia identichnost: teoriia i praktika [Social identity; theory and practice]. - Moscow: Modern University for the Humanities. [in Russian]

Skorokhodova, A.S. (1998). Graffiti: znachenie, motivy, vospriiatie [Graffiti: its meaning, motives, perception]. // Psychological Journal, 
19(1). [in Russian]

Voiskounsky, A.E. (2010). Psikhologiia i internet [Psychology and the Internet]. - Moscow: Akropol. [in Russian]

Zmanovskaia, E.V. (2012). Deviantnoe povedenie lichnosti i gruppy [Deviant behavior of individuals and groups]. - St. Petersburg: Piter. [in Russian] 